4. Andrew Robinson, "Dating Piranesi's Early 'Vedute di Roma'" Piranesi tra Venezia e l'Europe (Venice, 1983) $11 \mathrm{ff}$.

5. The "F-" and "H-" numbers refer to the two standard catalogues raisonnés of Piranesi's work, Henri Focillon, Giovanni-Battista Piranesi, essai de catalogue raisonné de son oeuvre, (1918): and Arthur M. Hind, Giovanni Battista Piranesi: A Critical Study, (1922).

\title{
"House Portraits" Four Krieghoff Oil Paintings at the McCord Collection
}

\author{
By Conrad E.W. Graham \\ Curator of Decorative Arts, McCord Museum of Canadian History
}

The McCord Museum of Canadian History acquired in 1990, as the gift of Mr. And Mrs. David M. Campbell, four "house portraits" by Cornelius Krieghoff. "House portraits" while popular and not unusual in Britain and the United States, are much less common in Canada and were commissioned only by the most well established citizens. These four Krieghoff paintings are an important addition to the McCord Museum's collection of historical paintings.

Cornelius Krieghoff was born in Amsterdam in 1815, the son of Ernest Krieghoff a wallpaper manufacturer of Düsseldorf, Germany and a Flemish mother. Brought up in Bavaria he is said to have studied painting in Düsseldorf ${ }^{1}$ and have travelled Europe as an itinerant musician and painter. In 1837 he emigrated to the United States and enlisted as an artificer in the American army. He made drawings for the army during the Seminole War in Florida. ${ }^{2}$ Discharged from the army in Burlington, Vermont in 1840, he married Emily Saintaguta of Boucherville, Quebec shortly thereafter, although no marriage certificate has been located. By 1841 the Krieghoff family was living in Montreal but in the middle of the year moved to Rochester, New York probably because he could not obtain enough work as an artist. By 1845 they had returned and had taken up residence in Longueuil. Krieghoff worked in the Montreal area until 1853 when he moved to Quebec where he remained until 1863 and to which he returned in 1869-1871. He died in Chicago in $1872 .{ }^{3}$ Krieghoff was trained in the German genre painting tradition, and the secular subject matter had a sense of immediacy that Canadian customers came to prefer over the more formal neo-classical subjects that had preceded Krieghoff in Canada.

The four "house portraits" painted by Cornelius Krieghoff in 1846, and now part of the McCord collection, were commissioned by the Hon. Edward Hale (1800-1875). They represent one of the earliest commissions that Krieghoff received upon setting up his studio in Montreal. In a letter from Fanny Hale to her brother Edward she makes reference to the fact that she is sending him sketches of the old house and how wonderful it will be to have them in colour, ${ }^{4}$ this probably refers to the sketchbook of her mother Elizabeth Hale now in the National Archives, Ottawa. ${ }^{5}$ This sketchbook includes six sketches of the manor at Ste-Anne-de-la-Pérade and were probably used by Krieghoff in preparing his composition. The two ancestral houses were most probably painted from engravings. Krieghoff would have considered this commission to be a very important one as it was this type of clientele which he both wished and needed to cultivate in order to survive in Canada. Likewise, when displayed in the Hale house, the paintings displayed their old and new world roots and that they were part of the "establishment".

The Hon. Edward Hale (1800-1875) was a businessman of some standing, a member of the House of Assembly for Sherbrooke and a Legislative Councillor. ${ }^{6}$ He purchased 600 acres on the banks of the St. Francis river in late 1833 or early 1834 and probably built the house "Sleepy Hollow" during 1834. The museum has portraits of both Edward and his wife signed and dated by Alonzo Slafter 1834, and Slafter is known to have been accepting commissions in Sherbrooke during this year. 


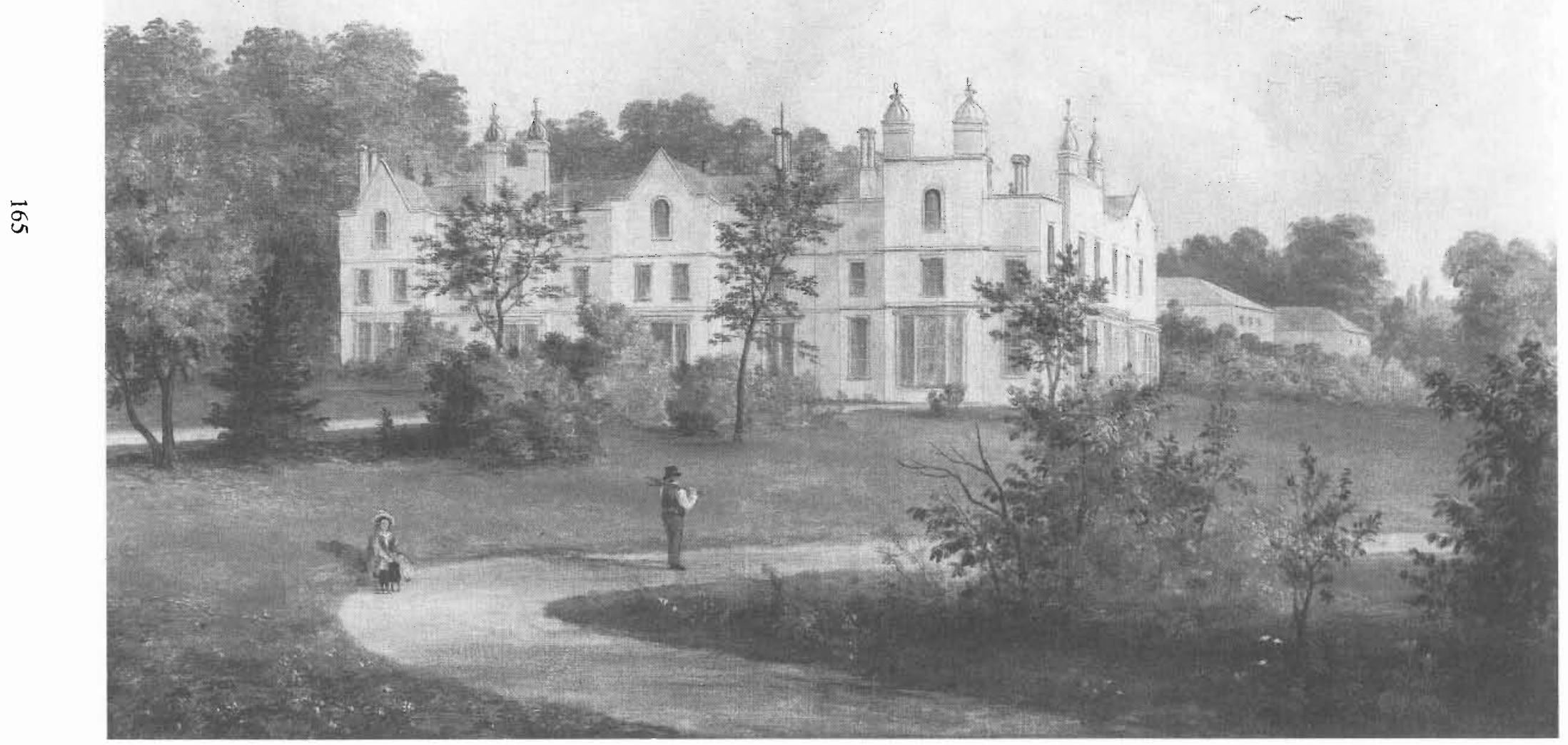

Cornelius Krieghoff (1815-1872), King's Walden Hertfordshire.

Oil on canvas, 1846; Size: $29.3 \times 39.7 \mathrm{~cm}$.

Gift of Mr. \& Mrs. David M. Campbell; McCord Museum of Canadian History, M990.758.1 


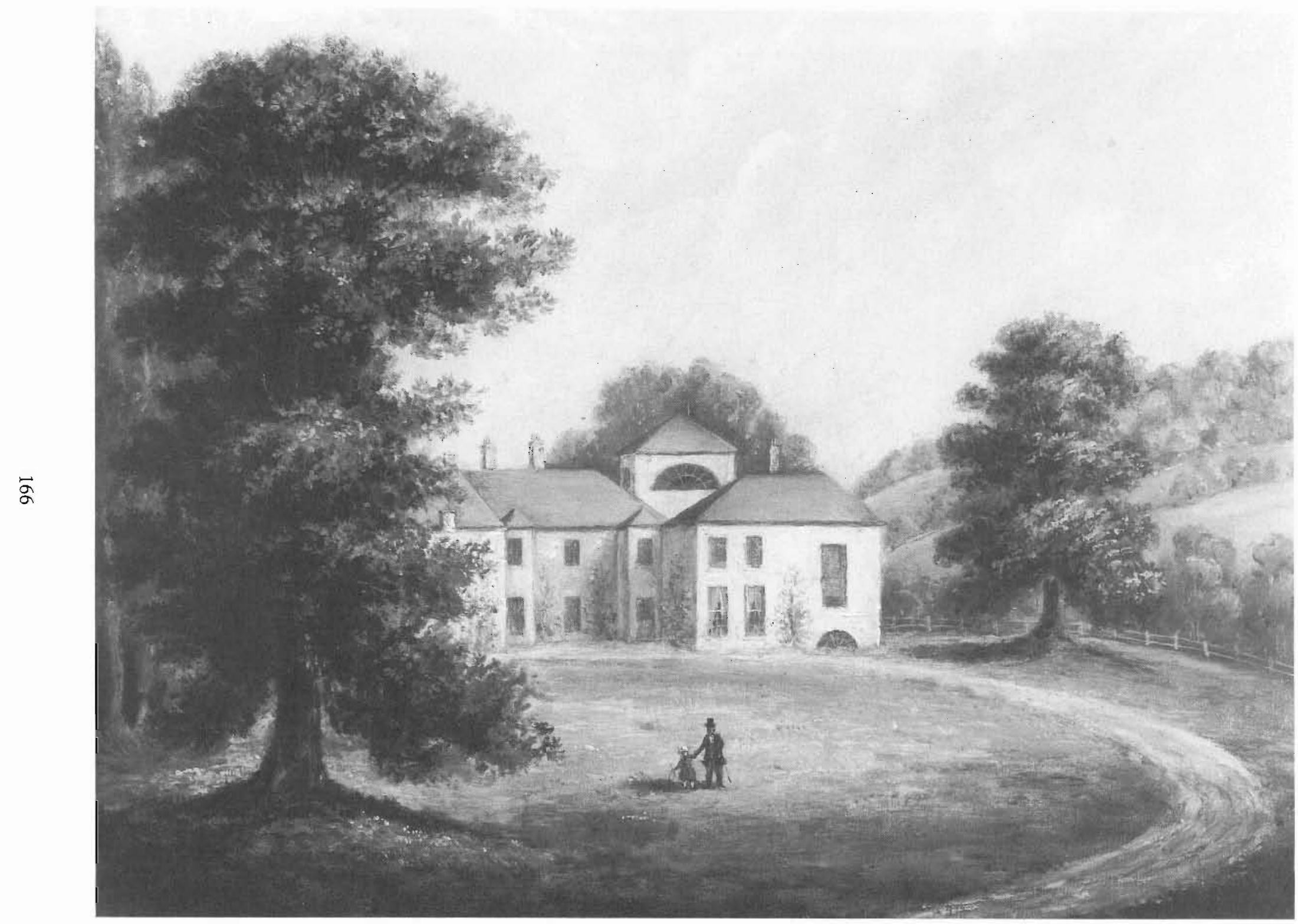

Cornelius Krieghoff (1815-1872), Plantation near Guisborough Yorkshire. Oil on canvas, 1846; Size: $29.0 \times 39.0 \mathrm{~cm}$.

Gift of Mr. \& Mrs. David M. Campbell; McCord Museum of Canadian History, M990.758.2 


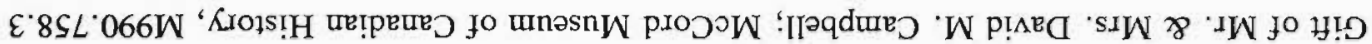

. w0 $8.6 \varepsilon \times 4.8 Z$ :əZ!S

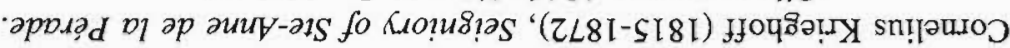

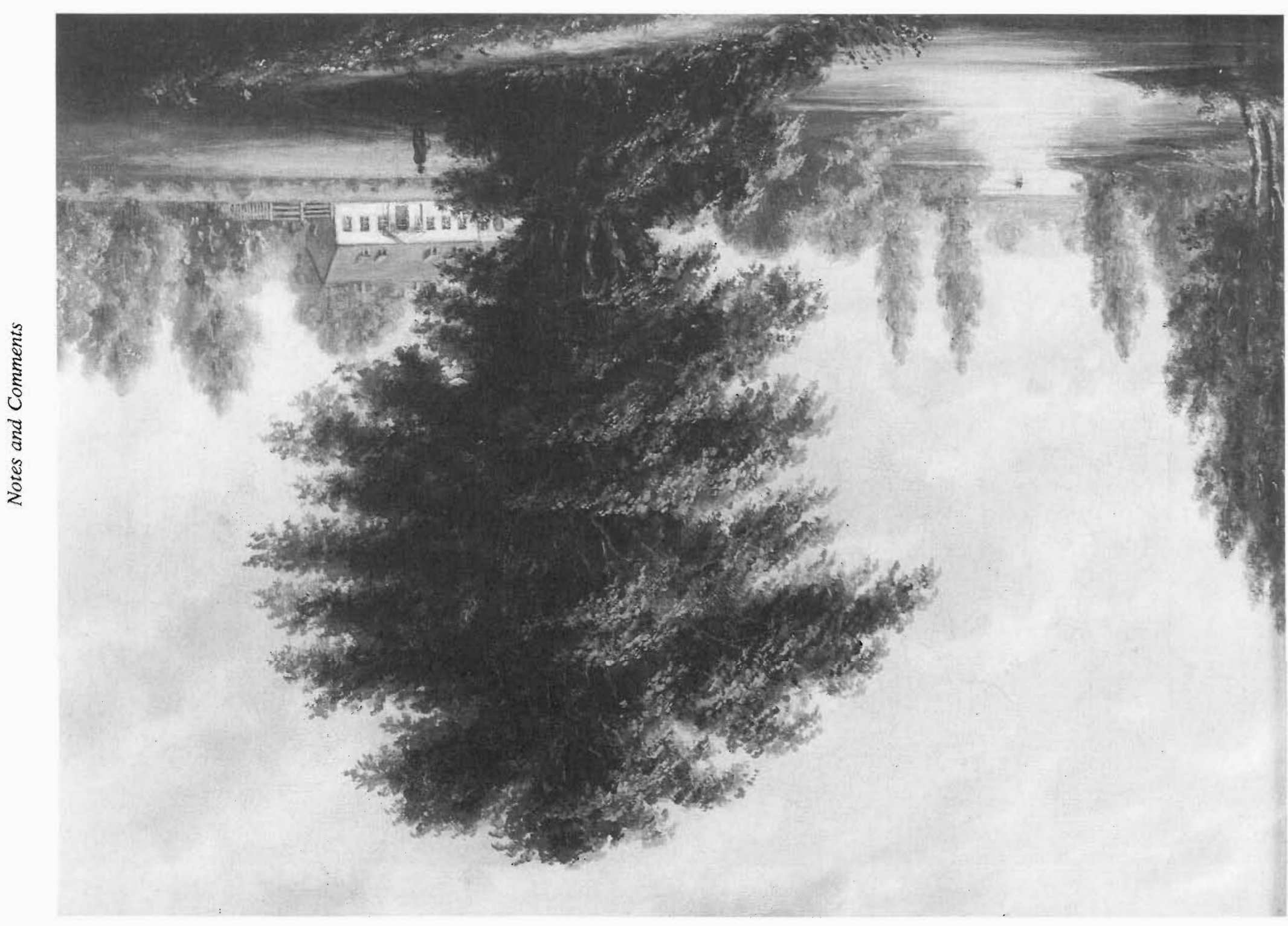




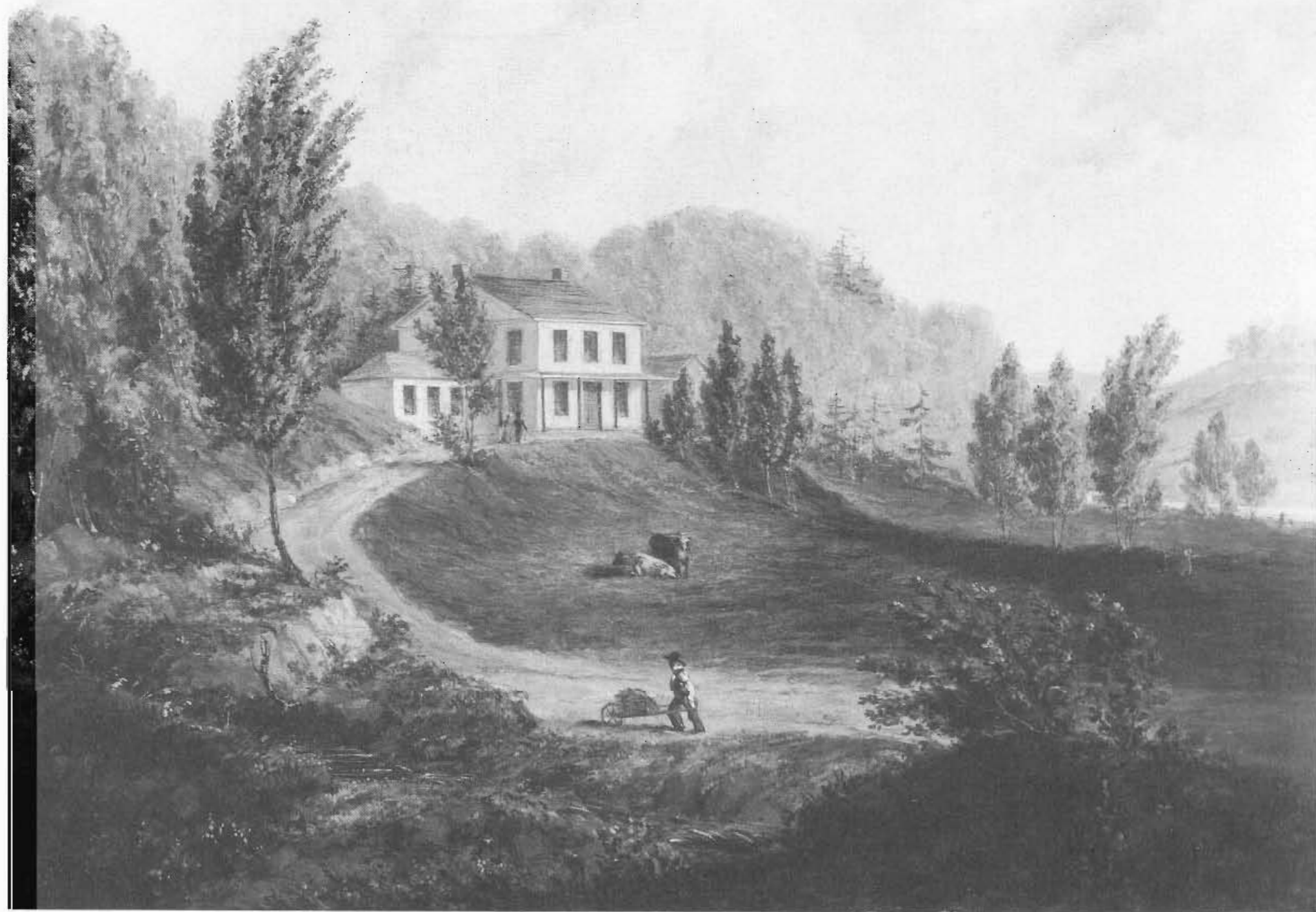

Cornelius Krieghoff (1815-1872), Sleepy Hollow Sherbrooke, Quebec. Oil on canvas, 1846; Size $29.3 \times 38.7 \mathrm{~cm}$.

Gift of Mr. \& Mrs. David M. Campbell; McCord Museum of Canadian History, M990.758.4 


\section{Notes and Comments}

Edward Hale's father John Hale (1765-1838) first came to Canada in 1793 as aide-de-camp and military secretary to Prince Edward Augustus, Duke of Kent (1767-1820). In 1799 he married Lady Elizabeth Frances Amherst (1774-1826) daughter of Lt. General William Amherst and niece of General Jeffrey Amherst and brought his wife to live in Quebec. He returned as deputy paymaster general and eventually was receiver general. He was a member of the Legislative Council from 1808 to 1838 and a member of the Executive Council from 1820 until his death. $^{7}$ On 27 September 1819 he bought the seigneury of Sainte-Anne-de-la-Pérade from Anne Tarieu de Lanaudière. It was an historic seigneury as Madeleine de Vercheres had come here as a bride in 1706. This became the family seat in Canada and summers were spent there until the return to Quebec for the winter social calendar.

The third painting represents the "Plantation" the house of Edward Hale's grandfather General John Hale (17281806). The property came to him through his wife Mary Chaloner (1743-1803) and was a portion of the old Chaloner grant of monastery lands near the town of Guisborough in Yorkshire. His grandfather had also had Canadian connections. As colonel in command of the 47th (Lascelles) Regiment, he joined with General Wolfe in the assault upon Quebec in 1759, and it was he who carried to England news of the victory and of the death of General Wolfe.

General John Hale had been born in 1723 at "King's Walden" depicted here as the fourth of the house portraits. This property had entered the family in 1575 and was purchased by Richard Hale a citizen and merchant of London who founded the grammar school in Hertfordshire. It had been a property of the Crown and is first listed in the Domesday Book as "Waldeni". The manor lies in the parish and village of King's Walden, Hertfordshire.

The four house portraits have come with a clear provenance having descended in the Hale family until their purchase by Mr. Campbell.

\section{Notes}

1. J. Russell Harper, Krieghoff (University of Toronto Press: Toronto, 1979), 5.

2. Ibid., 8 .

3. J. Russell Harper, Early Painters and Engravers in Canada (University of Toronto Press: Toronto, 1970), 184.

4. McCord Museum Archives, Hale Family Papers, 1846.

5. Colin M. Coates, "Like 'The Thames towards Putney' The Appropriation of Landscape in Lower Canada", Canadian Historical Review, Vol. LXXIV (number 3, September 1993), 317-343.

6. Dictionary of Canadian Biography (Vol. X), 326-327.

7. Dictionary of Canadian Biography (Vol. VII), 372-373. 